\title{
Socrates Among the Cicadas: The Art of the Platonic Dialogue
}

JS: At Monticello in I8I4, while designing the University of Virginia-that neo-classical masterpiece he called "an academical village"-Thomas Jefferson wrote to John Adams:

I am just returned from one of my long absences, having been at my other home for five weeks past. Having more leisure there than here for reading, I amused myself with reading seriously Plato's Republic. I am wrong however in calling it amusement, for it was the heaviest task-work I ever went through. I had occasionally before taken up some of his other works, but scarcely ever had patience to go through a whole dialogue. While wading thro' the whimsies, the puerilities, and unintelligible jargon of this work, I laid it down often to ask myself how it could have been that the world should have so long consented to give reputation to such nonsense as this?

Jefferson wisely surmises that Plato became "canonized" by the early Church fathers who saw in his mysticism the first tremblings of Christianity. Thus Platonism becomes grafted onto the simple teachings of Jesus to give them a classical pedigree.

But is Jefferson generally right about Plato's "unintelligible jargon"? Jefferson was no doubt reading Republic in Greek, so his views are not tainted by the treacle of translation. Jefferson claims- he is not alone in the charge- that Plato was a Sophist, despite how much Plato despised the Sophists. Far from practicing a subtle, supple dialectic, Plato's Socrates will go to any lengths to make his weaker argument appear the stronger-that is, to put his dialogic opponent in more and more untenable positions, no matter how absurd his own position became in the process.

How to cite this book chapter:

Begam, R. and Soderholm, J. 20I 5. Socrates Among the Cicadas: The Art of the Platonic Dialogue. In: Begam, R. and Soderholm, J. Platonic Occasions: Dialogues on Literature, Art and Culture. Pp. I59-I76. Stockholm: Stockholm University Press. DOI: http://dx.doi.org/Io.I6993/sup.baa.j. License: CC-BY-NC-ND. 
Was Plato "of the Sophist's party without knowing it"? And how much do our own dialogues represent a series of necessary footnotes to Plato? Or have we, in the preceding dialogues, engaged in a properly dialectical way of thinking? Does it finally take two minds to tango philosophically?

RB: There are two Platos: the didactic Plato of Republic, Crito, Phaedo and Timaeus and the ludic Plato of Symposium, Phaedrus, Theaetetus and Sophist. Which is the "true" Plato and which the "false"? Happily we need not choose. As Plato himself observes in Sophist, "when we say that which is not, we don't say something contrary [enantion] to that which is, but only something different [alla] from it" $(257 \mathrm{~b})$. Just as there is no single Shakespeare, there is no single Plato.

That Jefferson, Founder of the American Republic, regarded Plato's Republic as "whimsical," "puerile" and "unintelligible" is no surprise. The Declaration of Independence and the Constitution of the United States stand as far from The Republic-or Politeia ["civil polity," "form of government"] to give Plato's work its proper name-as Obama's Washington does from Pericles' Athens. Of course, the most influential negative account of Politeia came from Karl Popper, who argued that Plato's work provided a blueprint for twentieth-century totalitarianism. Eric Voeglin, Leo Strauss and Allan Bloom all persuasively answered, each in his own way, Popper's crude and reductive reading.

I myself like to imagine Politeia as a kind of utopic-dystopic novel, Plato's version of Book IV of Gulliver's Travels. Plato could never forgive Athenian democracy for having murdered his teacher and arguably the greatest man of the age. Having sweepingly condemned all forms of Greek government-timocracy, oligarchy, democracy and tyranny-he proposes an alternative that abolishes family, censors poetry and art, places men and women on an equal footing (a scandalous thought in Plato's time) and strikes at both aristocracy (men of "gold" may rise beyond their appointed rank, 4I5 a-b) and private property. In other words, he writes a book designed to offend everyone. What better way for Plato to vent his spleen against the city that killed Socrates? 
JS: Re-reading Theaetetus this morning I found myself writing (mentally) in the margins: "surpassingly clever; insufficiently dialectical." In terms both congenial and hostile to Socrates, I might accuse Plato/Socrates of being a disingenuous midwife, posing as someone who helps others to give birth to the truth, when in fact he is delivering himself of an entire nursery of Ideas. But in the other works you mention, Plato is more of a literary man and more or less convincingly dialectical. That raises the question of how seriously we can take his banishing of poets when Plato himself so often avails himself of figurative language, similes and allegories. Indeed, arguably his most famous glimpse of the form of the Good is presented in/as the allegory of the cave. We recall that allegoria is a "saying otherwise" or a "speaking differently" (this also accounts, in Greek, for Plato's using the alias of Socrates in the agora). Like Emily Dickinson, Plato is telling the truth, if not the Truth, but telling it slant. He is not "saying the thing which is not" but rather suggestively evoking logos in and through mythos-the dialectic as "hypotheses, underpinnings, footings, springboards" (Politeia VI, 5 I I b-c).

It is difficult to imagine that Jefferson dismissed these inspired moments of mythos as "whimsies." But Jefferson could have pointed to dozens and dozens of passages where Plato seems about as dialectically nimble as Polonius. Before turning to Politeia and its mixture of logic-chopping banality-not to mention, winged allegories and elastic springboards-let me detain you for a moment with a passage from Theaetetus.

THEAETETUS: Really, I am not sure, Socrates. I cannot even make out about you, whether you are stating this as something you believe or merely putting me to the test.

SOCRATES: You forget, my friend, that I know nothing of such matters and cannot claim to be producing any offspring of my own. I am only trying to deliver yours, and to that end uttering charms over you and tempting your appetite with a variety of delicacies from the table of wisdom, until by my aid your own belief shall be brought to light. Once that is done, I shall see whether it proves to have some life in it or not. Meanwhile, have courage and patience and answer my questions bravely in accordance with your convictions.

THEAETETUS: Go on with your questioning. ( 57 c-d) 
But is Plato-alias Socrates-really being the dialectical, midwifely equivalent of an "honest broker" here? He asks ridiculously leading, tempting and taunting questions in order to maneuver his interlocutors into more and more untenable positions. Can this nettling and hectoring really be passed off as midwifery? Or is the pose of the midwife one of the aliases by which the truth speaks otherwise, or differently? Is that variable, ambiguous position of the Socratic inquisitor midway between logos and mythos, the forward slash [/] eliding "either" and "or" and suggesting that Theaetetus (as well as the reader) must court the possibility that "what one believes" and "putting others to the test" are the yin and yang of Platonic dialectic? In other words, "Praise alla ..."

RB: The maieutic conceit frames Theaetetus. Socrates' interlocutor begins by confessing his inability to answer the question "What is knowledge [epistēmē]?" but Socrates reassures him, suggesting that he is "big with idea":

SOCRATES: This isn't lack of fertility, Theaetetus. You're pregnant, and these are your labor-pains.

THEAETETUS: I don't know about that, Socrates. I'm just telling you my experiences.

SOCRATES: Don't be so serious! Haven't you heard that my mother Phainarete was a good, sturdy midwife [maias]?

THEAETEUS: Yes, somebody did tell me once.

SOCRATES: And have you heard that I practice the same profession? (I48e-I49a)

By the end of the dialogue, Socrates, having demonstrated the insufficiency of all theories of knowledge, returns to the metaphor of midwifery:

SOCRATES: Well, are we still pregnant? Is anything relevant to knowledge still causing us pain, my friend, or have we given birth to everything?

THEAETETUS: I most certainly have: thanks to you. I've put into words more than I had in me.

SOCRATES: And does our midwifery declare that everything we produced was still-born and that there was nothing worth keeping? 
THEAETETUS: Absolutely.

SOCRATES: Well, Theaetetus, if you set out at a later date to conceive more ideas, and you succeed, the ideas with which you'll be pregnant will be better because of this inquiry of ours; and even if you don't get pregnant, you'll be easier to get on with, because you won't make a nuisance of yourself by thinking that you know what you don't know. This sopphrosunē [soundness of mind, moderation, discretion] is all my skill is capable of giving, nothing more. (2Iob-c)

One of Plato's great themes is that Socrates' ultimate wisdom consists in knowing only that he does not know, and at $\mathrm{I}_{5} \mathrm{~d}$ Socrates commends Theaetetus' own admission of ignorance as the basis for philosophy itself: "It looks as though Theodorus' sketch of your character was accurate, my friend. I mean, this feeling - a sense of wonder [thauma]-is perfectly proper to a philosopher: philosophy has no other foundation, in fact."

So is Socrates genuinely maieutic or does he simply give birth to his own ideas? By reminding us that Socrates follows his mother's profession, Plato may be slyly suggesting that his teacher's famous method is a form of intellectual autogenesis-that the offspring of Socrates' midwifery is none other than Socrates himself. But does it matter? Socrates is examining himself as much as his interlocutor. Indeed, in the Sophist, he defines the very object of philosophy—thinking [dianoia]—as "the soul's conversation with itself” (264a). And as I needn't tell you, the Greek word for conversation is dialogia.

All of which is to say, I find Theaetetus both surpassingly clever and surpassingly dialectical. As for your last question-is maieutics a method or a masquerade, a form of logic or of myth-I say Yes and Yes.

JS: Molly Bloom meets the Interior Paramour of Wallace Stevens. That coupling suggests that it takes only one to tango dialogically and dialectically. If so, then our own dialogues must be second-order productions, relying as they do on two minds wondering into discourse and debate. This discussion does make "one" wonder what we two are up to in our collection of dialogues. Let me say that I find the wisdom of Socratic ignorance so 
divertingly disingenuous that it must be, well, literary. Is this what you imply by your double affirmation "Yes and Yes"?

RB: Dialectic and dialogic begin in doubt, in being of two minds as the German Zweifel and the Italian dubitare suggest. Of course, one person can be of two minds, just as two people can be of one mind. For genuine dialogue to occur, what's important is not the number of participants but the nature of the activity.

The problem with the Sophist is that he knows in advance where he is going. There is no doubt, no wondering, no wandering. He hums along the highway of argument, disregarding the twists and turns demanded by logical progression and internal coherence. Ignoring the complex interplay of identity and difference-what Plato calls the "weaving together of forms" [eidōn sumplokē]—the Sophist separates what should be connected and connects what should be separate. In one of the truly astonishing moments in the dialogues, Socrates describes such crude logic-chopping as "the sign of a completely unmusical [amouson] and unphilosophical [aphilosophon] person" (Sophist, 259e). I say "astonishing" because amouson does not signify "unmusical" (as Nicholas White translates it) so much as "inaesthetic" or "indifferent to the Muses," which means that, here at least, Socrates gives equal weight to the claims of art and philosophy.

Then again, perhaps this moment is not so astonishing. As we have remarked, in the Platonic canon there are at least two Socrates, one of whom lingers with Phaedrus among the cicadas, those friends of the Muses who preferred art to life itself:

The story is that these creatures were once human beings, belonging to a time before the Muses were born, and that with the birth of the Muses and the appearance of song some of the people of the time were so unhinged by the pleasure that in their singing they neglected to eat and drink and failed to notice that they had died. From them the race of the cicadas later sprang. (Phaedrus, $259 \mathrm{~b}-\mathrm{c})$

JS: I am of one, two-no-many minds about your last observations. It is clear to me that our longish replies to each other in our dialogues are intellectual wanderings, divagations and investi- 
gations more or less animated (taking wing) from each other's thoughts and remarks. We are the heirs of Plato inasmuch as we hold forth like Socrates, drawing some dialectical electricity from each other but also giving birth to our own ideas. Plato did at least require the example, if not the spectacle, of Socrates pestering the hell out of Athenians in the marketplace, giving his fellow citizens a profound case of agoraphobia. Unlike the more eristic dialogues-where Socrates badgers his opponents into blandly reflexive agreement with all his views-we never reduce each other to a "yes man," despite your recent "Yes and Yes," which of course was the consummation of your Socratic peroration.

Speaking of doubt as a method of inquiry (including dubito ergo cogito ergo sum), I'd like to return to the passage you quoted earlier from Theaetetus when Socrates encourages young Theaetetus (I use the Cornford translation) "to find a single formula that applies to the many kinds of knowledge" (I48d). Theaetetus explains that he has tried to do this but cannot find any satisfactory solution. "And yet," says Theaetetus, "I cannot get the question out of my mind," to which Socrates replies, "My dear Theaetetus, that is because your mind is not empty or barren. You are suffering the pains of travail" (I48e). The importance of Socrates in the polis, and the larger point of Plato in Politeia, rests on how far one gets others to the point where they are fruitfully doubtful, rife with fecundating self-division and, therefore, incapable of sophistry. Hamlet epitomizes that state of mind with the most famous disjunction on the planet- "To be or not to be "- -and later in the play when he says, "In my heart there was a kind of fighting that would not let me sleep." That agōn, that strife, is what makes Hamlet the most beautifully doubtful creature ever penned by man or god. Endlessly bemusing himself, Hamlet is the most philosophical of princes.

Indeed, Hamlet is one of those who would rather listen to the husky music of the cicadas than do something so politically-pointed as skewer Claudius. "To be or not to be"-that is the question he cannot get out of his head and his own way of weaving together forms results in his seeing man as "this quintessence of dust." Hamlet finally comes to prefer the music of his own mind (his shaped sphere, his distracted globe) to life in rotten Denmark. He is of one, two-many minds about everything. Is Hamlet the quintessence of Socrates? 
RB: The peregrinating Prince engages in the "soul's conversation with itself," reading in the book of the self "words, words, words." To doubt is to be of more than one mind. It is to be manyminded, myriad-minded, possessed of a "negative capability" that enables the singular to become the plural. Hamlet, bounded in a nutshell, encompasses infinite space, discovering more in heaven and earth than is dreamt of in his or anyone's philosophy. But what of Plato, who in Parmenides and Sophist argues for both the One and the Many. Is he also myriad-minded?

Before becoming a philosopher, Plato tried his hand at writing tragedies, and it is worth remembering that most of his dialogues are polylogues, closet dramas complete with characters, settings and actions. Euthyphro, Apology, Crito and Phaedo constitute a tetralogy, which tells the tragic story of the death of Athens' greatest citizen. Like Achilles, Socrates is given a choice between glory and ignominy, and like Achilles he chooses the noble course, a point Plato drives home in Crito (44b) when he compares Socrates to the hero of The Iliad.

But it is not only Plato's tetralogy that employs dramatic forms and themes. Most of the dialogues take as their title the name of a youth of noble origin, who emerges as Plato's dramatic hero and whose interrogation by Socrates constitutes the central "action" of the dialogue. Admittedly, these dramas are internalized, with conflicts and resolutions that are psychological and philosophical, but their structure is surprisingly Aristotelian. So it is that virtually every dialogue is built around a moment of peripeteia or reversal in which the hero is "turned around," forced to renounce a doctrinal system, whether it comes from Protagoras or Parmenides or Heraclitus. How does Plato characterize the "error" that leads the hero to "fall" into "false belief"? In Theaetetus, Socrates calls it hamartia (I 89c), the very word Aristotle later uses to describe the "flaw" or "error" of the tragic hero. It is especially revealing to see how Plato anatomizes hamartia in Phaedrus: "When judgement leads us by reason towards the best and is in control, its control over us has the name of restraint [sōphrosunē]; when desire drags us irrationally towards pleasures and has established rule within us, its rule is called by the name of excess [bubris]" $(237 \mathrm{e}-238 \mathrm{a})$. That hubris is the most common source of hamartia is a truism, 
it seems, not only of tragedy but also of the Platonic dialogue. And where does this internalized drama of the soul finally lead? For Aristotle tragedy achieves its critical mass, its moral and emotional coherence, in the moment of anagnōrisis or "recognition," when the hero finally gains "knowledge" [gnosis] of his situation and himself.

Most Platonic dialogues also reach their climax in a moment of anagnōrisis but with this difference: the young man achieves a specific kind of knowledge-a sōphrosunē or the "modesty" that comes from understanding the limits of knowledge. Here is the conclusion of Theaetetus, where Socrates reviews and rejects all the possible definitions of knowledge that he and his interlocutor have considered: "Therefore, Theaetetus, knowledge [epistēmē] can be neither perception, nor true belief, nor true belief with the addition of rational account" (2 Ioa-b). As Socrates explains in the Apology (20e), the Oracle of Delphi has declared him the wisest of men because he alone knows that he knows nothing. This is indeed the "ultimate" knowledge that Socrates imparts to his followers. Philosophy not only begins in wonder-in being of two minds-it ends in it.

JS: You make a strong (novelistic) case for Plato's being on the side of artists in the ancient quarrel between poetry and philosophy. Therefore, there must have been more than a touch of irony in his infamous banishment of poets from the utopian state. You have admirably depicted Plato wrestling with Homer and the tragedians for the hearts, souls and minds of the Athenians. He must outwit them at their own games, participating in a literary Olympiad where the unlikely hero is an ugly old man with bulging eyes and snub nose.

But does Plato's philosophy end in wonder? In many dialogues we are given plenty of hints to a higher wisdom that has gone far beyond doubt. The culmination of that wisdom is the theory of Forms and particularly the Form of the Good. What is peculiar is how Plato must resort to literary techniques to intimate that higher knowledge, that moment when doubtful doxa gives way to the excellence [arête] of epistemen. We are not always left, that is, with Socratic irony, but sometimes with Platonic metaphysics, the recognition that one is 
flourishing in the sunlight of Reason, Truth and Goodness once one has emerged from the cave of shadows and illusions.

So I am forced to drive a wedge between Socrates, who wrote nothing, and Plato, who wrote voluminously, giving his teacher all his own views, standing behind him as the first term stands "behind" the second term in "Plato/Socrates." But would Socrates "stand behind" (support, endorse) any of Plato's metaphysical views? Is Socrates a persona for Plato the way Marlow is a persona for Conrad? These considerations necessarily bring to mind Derrida's perversely brilliant reading of the medieval depiction of Plato standing behind a scribal Socrates.

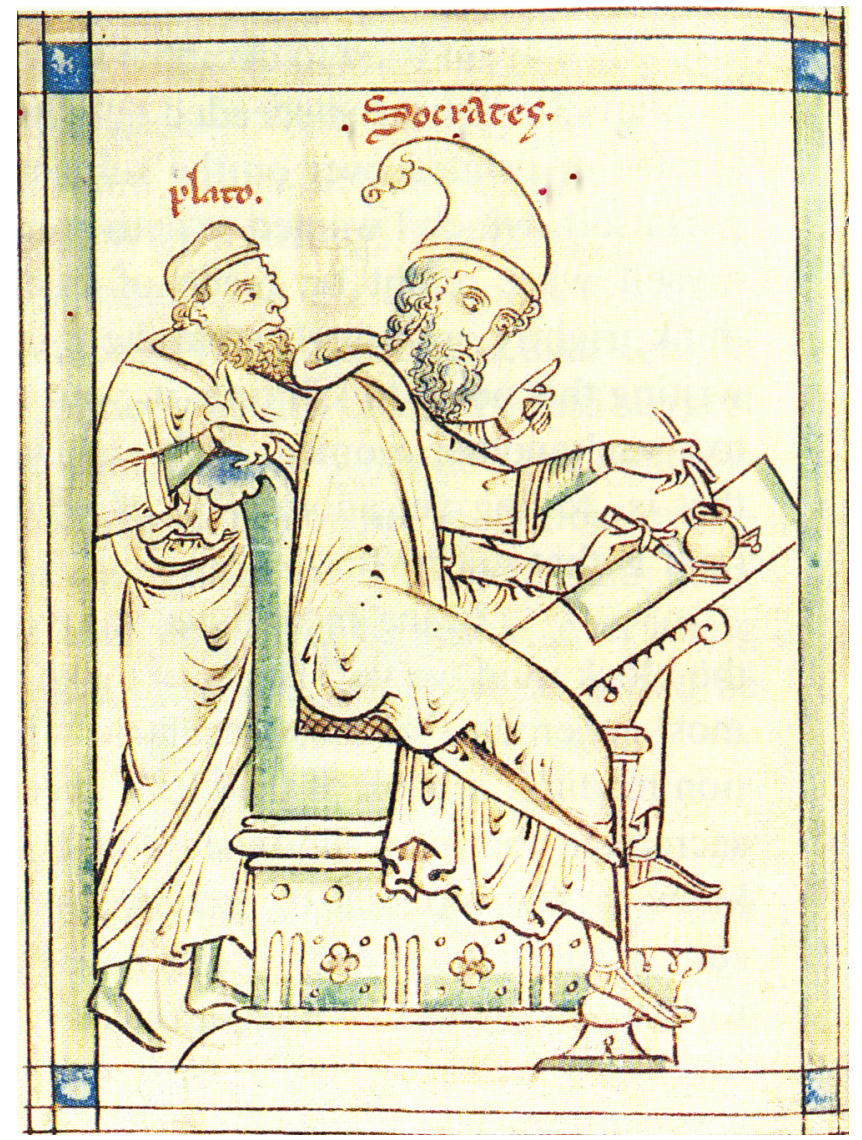

Figure 10: Frontispiece, Prognostica Socratis Baseilei. 
A theoretically-tumescent Derrida gazes at this "post-card" and tosses off the following:

The card immediately seemed to me, how to put it, obscene ... For the moment, myself, I tell you that I see Plato getting an erection in Socrates' back and see the insane hubris of his prick, an interminable, disproportionate erection ... slowly sliding, still warm, under Socrates' right leg ... Imagine the day, when we will be able to send sperm by post card ... [And, finally, Plato] wants to emit ... to sow the entire earth, to send the same fertile card to everyone. (La Carte Postal)

I will add nothing to this astonishing observation except to remark that sopphrosunē is in jeopardy. But whose lack of restraint is it: Plato's or Derrida's? Whose seminar is being "emitted"? Is Derrida's interpretation of the image (and the scene of writing) obscene or has he put his finger on something erotically overdetermined in the relationship between Plato and Socrates, something perhaps more subtly suggested by Socrates and Phaedrus "making love" [of wisdom] among the cicadas? So what do you make of the visual peripeteia of the image above and what it suggests about the literary uses-and abuses-of Socrates?

RB: My case is not for a novelistic but a theatrical Plato, one who wears masks, speaks in different voices and manipulates appearance and reality, like the wizard [pharmakeus] to which Socrates is compared, even as he insists that such mimetic legerdemain is a crime against the polis: "So if we are visited in our state by someone who has the skill to transform himself into all sorts of characters and represent all sorts of things, and he wants to show off himself and his poems to us, we shall treat him with all the reverence due to a priest and a giver of rare pleasure, but shall tell him that he and his kind have no place in our city" (Politeia III, 398a). Remember what Alcibiades says of Socrates: He is a Silenus (2 I 5 b), whose trompe l'oeil exterior bears no resemblance to what lies within, a man who "spends his whole life being ironic [eirōneuomenos] and playing games [paizōn] with people" (Symposium 2 16e). Could anything be more playfully ironic than ironically banishing the player from the stage? 
But, you will ask, pose and posture as Socrates does, isn't the Man behind the Mask, the God within the Silenus, the eidos above eikasia, finally a metaphysician who scolds us benighted humans out of the Cave of Illusion and into the Light of Truth? After all, Socrates's larger argument in Theaetetus consists in demonstrating to his young charge that the Sophists are wrong, that perception (shadowy aisthēsis) is neither knowledge [epistē$m \bar{e}]$ nor truth [alètheia]. Indeed, isn't Plato's condemnation of art-of the aesthetic-predicated on the claim that aisthe sis is an empty and illusory form of belief [doxa], the opposite of true knowledge, which is to be found only in the realm of the eternal Forms?

To which I can only say, “Yes ... but.” Consider the explanation of the Forms in Phaedrus:

Now the region above the heavens has never been celebrated as it deserves to be by any earthly poet, nor will it ever be. But it is like this-for one must be bold enough to say what is true, especially when speaking about truth. This region is occupied by being [ousia] which really is, which is without colour or shape, intangible, observable [theatē] by the steersman of the soul [psuchē] alone, by intellect [nous], to which the class of true knowledge [alēthous epistēmēs] relates. $(247 \mathrm{c}-\mathrm{d})$

Notice that Socrates does not tell us what the Platonic heaven is, but what it is like. Of particular interest is his use of the word theate ["visible," "observable," "see-able"]. I said earlier that Plato's dialogues function as internalized dramas, a kind of theatre of the mind, and it is precisely this theatricality that is essential to Plato's idealism. How does one render perceptible what is colorless and shapeless? How does one look upon [theaomai] what cannot be looked upon [theateos]? One makes the eidos "visible" [theatē] by constructing a place of seeing, a theatron or theatre. Hence, Plato writes not merely dialogues but closet dramas, a marriage of literature and philosophy in which the abstract is made concrete and the concrete is made abstract. Socrates may be-to speak the language of Wittgenstein-the ladder Plato wishes to throw away. But Plato cannot reach the metaphysical high ground without him. 
As for that posed card, I will be happy to comment, but I have rambled on long enough and am keen to have your own response to Derrida's “preposterous” reading.

JS: That your theatrical Socrates would be banished forthwith from Plato's rational utopia is a gymnastic irony unappreciated-and indeed undetected-by most philosophers. And by theologians for that matter. The wholly, holy and ineffable nature of Plato's Good is precisely what made it so suggestive to the early Church Fathers who wanted to see in Greek philosophy the germ or embryo of Christian metaphysics. Paul had no trouble making the Unknown God on the Areopagus into the One, True God. That was awfully clever and opportunistic of him. The idea of a "theatrical Plato" who performs all the tricks you mention would have been anathema to Aquinas and St. Augustine, not to mention Plotinus, that reverential and deeply humorless repriser of Platonic ideas. But I do think there is something reductive and dismissive about treating Plato's ideas divorced from their dramatically-signifying contexts. And you are right to remark his necessarily figural commitments as he tries to intimate the intelligible realm in and through material gleaned from the visible realm (the divided line is caught in the loop of metaphor). As Lacan says to St. Paul's "The Letter killeth but the Spirit giveth life"— "Yes, but how does Spirit live except in the Letter?"

Plato's "ladder of love" in Phaedrus is most efficiently-and amusingly—reconstructed (in reverse, no less) in one of my favorite moments from Byron's comic masterpiece:

'Tis the perception of the beautiful

A fine extension of the faculties, Platonic, universal, wonderful,

Drawn from the stars, and filter'd through the skies,

Without which life would be extremely dull;

In short, it is the use of our own eyes,

With one or two small senses added, just

To hint that flesh is form'd of fiery dust. (Don Juan II, 2 I 2)

"[F]iltered through the skies" of allegory and simile, Plato's kaloi reach down into our fiery flesh and quicken our impulses 
for both erōs and epistēmè. That is the genius of the dialogues and their dialectic at their best. The mental theatre you suggest is "drawn from the stars" but it is also very much staged for our sensuous enjoyment. A contradiction-or an ancient quarrelemerges between philosophy and literature only insofar as we take seriously Plato's most astringent pronouncement against poetry and poets in Politeia. But this still leaves us with the meaning of that damned postcard.

RB: My reading of Derrida's reading: fantasy and selfprojection. Derrida would like to do to Plato what he accuses Plato of doing to Socrates. He deliberately takes him the wrong way, turns him around, reverses him. Hence Platonic insemination—see Phaedrus - becomes Derridean dissemination; Platonic erection-mental and physical-becomes Derridean deconstruction. But the Jacques therapy doesn't quite come off. It leaves the Frenchman, rather than the two Greeks, looking limp: an unhappy instance of hamartia or "missing the mark."

As for the Church Fathers, I have no doubt that they would have shuttered the Platonic theatre, had they recognized it, just as surely as the Puritans shuttered the English theatre in I642. Presumably they read a dialogue like Phaedrus selectively, turning a blind eye to those moments when the Platonic flesh catches fire: "Once [the lover] has received the emanation of beauty through his eyes, he grows warm, and through the perspiration that ensues, he irrigates the sprouting of his wing. When he is quite warm, the outer layers of the seedling unfurls ... [and] as nourishment streams upon it the stump of the wing begins to swell and grow from the root upward as a support for the entire structure of the soul" (25 Ib). What, one wonders, would Thomas Aquinas have made of a passage like this?

Of course, if sensuous apprehension [aisthēsis] is continuous with spiritual knowledge, if the ladder of erōs leads to the heaven of eidos, then are we dealing with a fully aestheticized Plato, with a Socrates who not only lingers among the cicadas but also luxuriates in them? Nietzsche acknowledges the dramatic element in the dialogues, but he rejects the aesthetic reading: 
Socrates, the dialectical hero of the Platonic drama, reminds us of the kindred nature of the Euripedean hero who must defend his actions with arguments and counterarguments and in the process often risks the loss of our tragic pity; for who could mistake the optimistic element in the nature of dialectic, which celebrates a triumph with every conclusion and can breathe only in cool clarity and consciousness-the optimistic element which, having once penetrated tragedy must gradually overgrow its Dionysian regions and impel it necessarily to self-destruction-to the deathleap into bourgeois drama ... Optimistic dialectic drives music out of tragedy with the scourge of syllogisms; that is, it destroys the essence of tragedy. (Birth of Tragedy, section I4)

What are the limits to treating Plato as a Friend of the Muses as well as of the Forms? Does dialectic finally undermine drama by rationalizing and systematizing it? It is perhaps worth pointing out that when Socrates speaks of the cicadas "conversing" among themselves, the verb he uses is dialegesthai (259a): "to engage in dialectic."

JS: Like Derrida's projection-fantasy in La Carte Postale, Nietzsche's reading of Socrates in "The Problem of Socrates" is also laced with the author's own profound anxieties and misgivings about his "position" as a philosopher in a cultural (and academic) environment deeply suspicious of his ideas. "The Problem of Socrates" begins to look like a double-portrait: of Socrates (the "Jew against Greek civilization") and of Nietzsche (the mad professor against the decay of European civilization). Both philosophers are speaking unpleasant truths, presenting untimely meditations and remarking the twilight of various idols, in Nietzsche's case the death of God Himself. Nietzsche's following remarks are wonderfully intriguing in this regard:

Is the irony of Socrates an expression of revolt? Of plebeian ressentiment? Does he, as one oppressed, enjoy his own ferocity in the knife thrusts of his argument? Does he avenge himself on the noble audience he fascinates? As a dialectician, he holds a merciless tool in his hand; he can become a tyrant by means of it; he compromises those he conquers. The dialectician leaves it to his opponent 
to prove that he is not an idiot: he enrages and neutralizes his opponent at the same time. The dialectician renders the intellect of his opponent powerless. Indeed, in Socrates, is dialectic only a form of revenge?

I have explained how it was that Socrates could repel: it is therefore all the more necessary to explain how he could fascinate. That he discovered a new kind of contest, that he became its first fencing master for the noble circles of Athens, is one point. He fascinated by appealing to the competitive impulse of the Greeks-he introduced a variation into the wrestling match between young men and youths. Socrates was a great erotic. (Twilight of the Idols, 7-8)

The role of Socrates as erotic dialectician is what makes Phaedrus such compelling reading. I think you're right to observe that Nietzsche ignores—or represses—-the "aesthetic Socrates" but he does acknowledge the erotic dimension of the ugly, old Greek, his capacity to fire up Athenian youths by demonstrating to them the distinctive pleasures in the agōn[y] of dialectical repartee, particularly when those intellectual debates occur in olive groves, the whirring music of the cicadas inspiring the husky melodies of Socrates and his beautiful pupil in conversation. Like cicadas, they forget to eat and drink, so ravishing is the sound of their own minds in concert. Both early theologians and, for that matter, Nietzsche, are deaf to that sensuously-rational music. The "two Platos" you mentioned earlier in this dialogue are reduced to one, who is either a forerunner of Christian asceticism or Nietzsche's resentful logician who likes to stab people with arguments. The aesthetical, "literary" Plato we have been discussing understood that erōs, eidos and epistēmē are dialectical kissing cousins, as hard to separate as dancer and dance.

RB: I take Nietzsche's reading of Socrates more seriously than I do Derrida's comments on the post card. Certainly there is a case to be made for the proposition that in Euripedean tragedyironic, dialectical, polemical-Socrates has replaced Dionysos and Apollo as the reigning deity of the Attic stage. I wouldn't say that Nietzsche represses the "aesthetic" Socrates, but that he regards this Socrates as overly and aridly Apollinian: "Now we should be 
able to come closer to the character of aesthetic Socratism, whose supreme law reads roughly as follows, 'To be beautiful everything must be intelligible,' as counterpart to the Socratic dictum, 'Knowledge is virtue'" (Birth of Tragedy, section I2).

But here I think Nietzsche errs, for, as we have discussed, the Socratic dictum is not "Knowledge is virtue" but "Knowledge of one's ignorance is virtue," the sopphrosune that enables dialectic wondering and wandering. That Nietzsche is also, as you point out, anxiously positioning himself in relation to his own time and place further complicates his brilliant but tendentious insights into Plato. Nietzsche's self-projection becomes unmistakable in Birth of Tragedy when he addresses the question of whether an "artistic Socrates" is possible: "For with respect to art that despotic logician occasionally had the feeling of a gap, a void, half a reproach, possibly a neglected duty. As he tells his friends in prison, there often came to him one and the same dream apparition, which always said the same thing to him: 'Socrates, practice music"' (section I4). In the Greek, "practice music" is mousikēn poiei, which might better be translated as "Dedicate yourself to the Muses!" or more simply "Create art!" (Phaedo, 6oe). Later Nietzsche returns to this moment in Crito, speculating on the prospects for a contemporary "artistic Socrates," who would philosophize not with a hammer but a tuning fork: "Here we knock, deeply moved, at the gates of present and future: will this 'turning' lead to ever-new configurations of genius and especially of the Socrates who practices music?" (section I 5). The "turning" or peripeteia that Nietzsche contemplates-casting himself in the role of an artistic Socrateswould have the happy effect of restoring a proper balance to the Apollinian and the Dionysian, to thought and feeling, philosophy and art.

One wonders what Jefferson, if he had summoned the "patience" to "go through a whole dialogue," would have made of such a Socrates, one who dedicates himself to the Muses, one who creates art.

JS: It is more and more apparent to me that Jefferson was not on the alert for those literary dimensions of Plato's thought you have so ably adumbrated and celebrated in the last few pages. 
Perhaps Symposium or Phaedrus would have stimulated his interest a bit more. Politeia can be a dreadful bore at times, particularly in the early books where Socrates is just demolishing opponents (the Thrasymachus set-to in Book 3, for example) in ways that also seem somewhat to justify Nietzsche's "resentful" observations. I think there are more than two "Platos," and perhaps that plurality of philosophical personae is both cause and effect of all Platonic occasions, re-presenting in one form or another, the most ancient of all philosophical problems-and the source of dialogue itself-the One and the Many. 